\title{
Socio-Environmental, Residential and Health Effects of Waste Dumpsites in Igando- Alimoso area of Lagos, Nigeria
}

\author{
ALIU, IR \\ Department of Geography and Planning, Lagos State University, Ojo, Lagos Nigeria \\ Email: ibrahim.aliu@lasu.edu.ng
}

\begin{abstract}
Urban planners and scholars have long been concerned about the negative impacts of improper management of waste on the quality of life of urban residents globally. This study therefore examined the socioenvironmental, residential and health impacts of waste dumpsites in Igando-Alimoso area of Lagos Nigeria using a cross sectional design to survey residents around the dumpsite facilities. Results showed that the waste dumpsites/landfill facilities have negative social effects resulting from the discomforting odors that ooze out regularly in the area. There was a perception of the landfills as constituting social nuisance to the community. The residents believed that the landfills were responsible for flooding, groundwater pollution, traffic jams, traffic noise, and residential dissatisfaction in the area. Also, in terms of health, waste landfills at Igando were perceptively linked with many diseases around the area, chief among which are typhoid, malaria, dysentery and cholera. With a Chi-square $X^{2}=72.56, \mathrm{DF}=4, \mathrm{p}<0.05$, at $95 \%$ confidence level, it was established that waste dumpsites were responsible for some illnesses in the study area. This study has strong policy implications for urban planning, real estate and public health in Lagos.
\end{abstract}

\section{DOI:https://dx.doi.org/10.4314/jasem.v25i6.12}

Copyright: Copyright (C) 2021 Aliu. This is an open access article distributed under the Creative Commons Attribution License (CCL), which permits unrestricted use, distribution, and reproduction in any medium, provided the original work is properly cited.

Dates: Received: 20 March 2021; Revised: 27 April 2021; Accepted: 07 May 2021

Keywords: Environmental degradation, health depreciation, residential dissatisfaction, waste dumpsites

Waste management usually conceived as the collection, transport, processing, recycling or disposal of waste materials in an effort to reduce their negative effects on human health, physical environment and socio-economic wellbeing of the residents has been a global challenge since the $20^{\text {th }}$ century (UNHABITAT, 2010; Aliu et al., 2014; Babalola, 2008; Agwu, 2012; Ogwueleka, 2003; Ukpong and Udofia, 2011; Wilson and Scheinberg, 2010; Przydatek and Kanownik, 2019). Poor and improper management of municipal solid waste (MSW) has negative impacts on the physical environment, health and social wellbeing of immediate communities. The developing countries including Nigeria are overwhelmed by the shear rapid population that generates huge sum of waste daily and the lack of capacity by the municipal governments to recycle and reuse most of the generated wastes leading therefore to waste backlog and dumping. Without waste minimization, recovery, recycling, reuse or recovery in developing countries wastes are either incinerated or dumped in poorly engineered landfills or simply in nearby lagoons, rivers, lakes, or in designated location on the streets constituting terrible threats to the urban residents socially, economically and environmentally. About $70 \%$ of all wastes in sub-Saharan Africa are deposited in landfills across the cityscape (Tomita et al., 2020). Overtime these landfills pollute and cause serious socio-environmental and health effects on the communities where they are located. Studies have shown that some waste dumpsites in developing countries are unsanitary and poorly managed leading to residential relocation, real estate devaluation, health, social and environmental problems (Agunwamba, 1998; Egbere et al., 2000; Lasisi, 2007; Olufemi, 2011).The management of municipal solid waste (MSW) is one of the challenges facing many urban areas in the world although the developing countries are most hit (Ogwueleka, 2003; Aliu et al., 2014; Tomita et al., 2020). While the developed economies with the $16 \%$ of global population generate 683 million tonnes of waste every year the subSaharan Africa generate 174 million tonnes of waste per year and is expected to generate about 516 million tonnes of waste per year by 2050 (Kaza et al., 2018). The numerous issues underlining MSW management 
in urban areas of developing economies have been widely documented (Agunwamba, 2003; Ogwueleka, 2003; Momoh and Oladebeye, 2010; Olorunfemi, 20111). In Nigeria 25 million tons of solid wastes are generated yearly (Ogwueleka, 2009). In a study of waste disposal management in Ado-Ekiti a rapidly growing city in south western part of Nigeria, Olorunfemi (2011) noted that the problems with waste management in the city come from increasing urbanization and disposal methods, especially where to locate the disposal facilities such as landfills, sewage treatment plants and incinerators. At the core of solid waste management problem in Nigerian cities are inadequate policies, lack of enabling legislation, poor public enlightenment, inappropriate technology, lack of waste infrastructural maintenance, poor waste collection operation, noncommittal posture of waste management workers, attitude of the public group behavior, education, and corruption (Agunwamba, 1998). Ogwueleka (2009) presented a study on the solid waste management in Nigeria cities, which is characterized by inefficient collection method, insufficient coverage of the collection system, and improper disposal. In Onitsha waste collection vehicles spend three to four hours per day making two trips per day to the disposal sites, vehicles are damaged by the rough street roads in the suburbs while the inner city wastes are mobilized by a group of scavengers (Ogwueleka, 2003). Agwu (2012) discussed the issues and challenges of solid waste management in Port Harcourt using behavioral approach. The author examined the relationship between some demographic variables of residents and the level of awareness, knowledge and practices of solid waste management in the city and found that significant relationship exist between them. Increasing number of urban populations is being exposed to the risk of waste pollution around landfills and this has raised serious social, environmental and health concerns particularly for individuals and vulnerable groups living around the dumpsites. The poorly managed waste management facilities such as dumpsites and landfills could lead to environmental pollution and epidemics such as E. coli, Staphylococus Aureus, and Samonela Sp., discourage tourist interest and promote undesirable residential mobility (Egbere et al., 2000; Agunwamba, 2003; Lasisi, 2007; Shamshiry et al., 2011). Studies have shown that residents living very close to the poorly maintained dumpsites or landfills risk contracting both communicable and noncommunicable diseases including typhoid, asthma, tuberculosis, fever, cancer, community health problems (Tomita et al., 2020; Ziraba et al., 2016; Przydatek and Kanownik, 2019; Mataloni et al., 2016). In addition the physical environment is likely to be negatively impacted by polluted landfills causing both social and physical problems like noise, pollution, offensive odors, vermin attack, accident, groundwater pollution, fire, land incidences and a host of other unthinkable consequences. Majolagbe et al. (2017) and Salami and Susu (2019) found that leachate around the dumpsites had contaminated the groundwater in the community.

Given the social, environmental and health risks posed by waste dumpsites in populated communities, it is imperative that more studies be conducted on the impacts of waste landfills on the adjacent communities. The aim of this study therefore is to evaluate the socio-environmental, residential and health impacts of waste dumpsites/ landfills on the residents living around the sites in Igando area Lagos.

\section{MATERIALS AND METHODS}

Study Area: Figure 1 shows the study area- Igando waste dumpsites - in Alimoso local government area, Lagos. The three dumpsites are situated on longitude $3^{0} 26^{\prime} \mathrm{E}$ to $3^{0} 25^{\prime} \mathrm{E}$ and latitude $6^{0} 56^{\prime} \mathrm{N}$ to $6^{0} 57^{\prime} \mathrm{N}$ in Alimoso LGA. The study area was located in the old Alimoso Local Government Area (LGA) which is in the North-western part of Lagos state. Alimoso LGA occupies a land area of 173.6sq km. The River Owo demarcates the study area from Ado-Odo/Otta Local Government Area of Ogun state on the Northern and western side. Towards the east it is bounded by Ifakoijaiye, Agege and Ikeja local government areas of Lagos state. The old Abeokuta express way forms the frontier line between these local government areas. On the Southern parts, the study area is bounded by Oshodi/isolo, Amuwo-Odofin and Ojo local government area of Lagos state. Alimoso is a local government area in Lagos Nigeria. It is the largest local government in Lagos with a population of $1,288,714$ people as at 2006 (NPC, 2007). Alimoso was carved out of Ikeja LGA in 1991 by the military government of Nigeria. In 2003 Alimoso LGA was split into six local council development areas (LCDAs) namely Agbado/Oke LCDA, Ayobo/Ipaja LCDA, Alimoso LGA, Egbe/Idimu LCDA, Ikotun/Igando LCDA, and Mosan Okunola LCDA. A vast area of the LGA consists of urban populations. As a settlement or community Alimoso town was established in 1945 by predominantly Egbados and Aworis. The indigenous inhabitants were traditionally peasant farmers, although commercial, private service, 
public service and industrial activities dominate the community presently. Culturally Alimoso is part of the Yoruba kingdom extending from the central middle belt of Nigeria to the south western area extending to Togo in western Africa sub region. Igando community is part of the newly created LCDAs named Ikotun/Igando LCDA. The administrative headquarters of Ikotun/Igando LCDA is at Ikotun town.

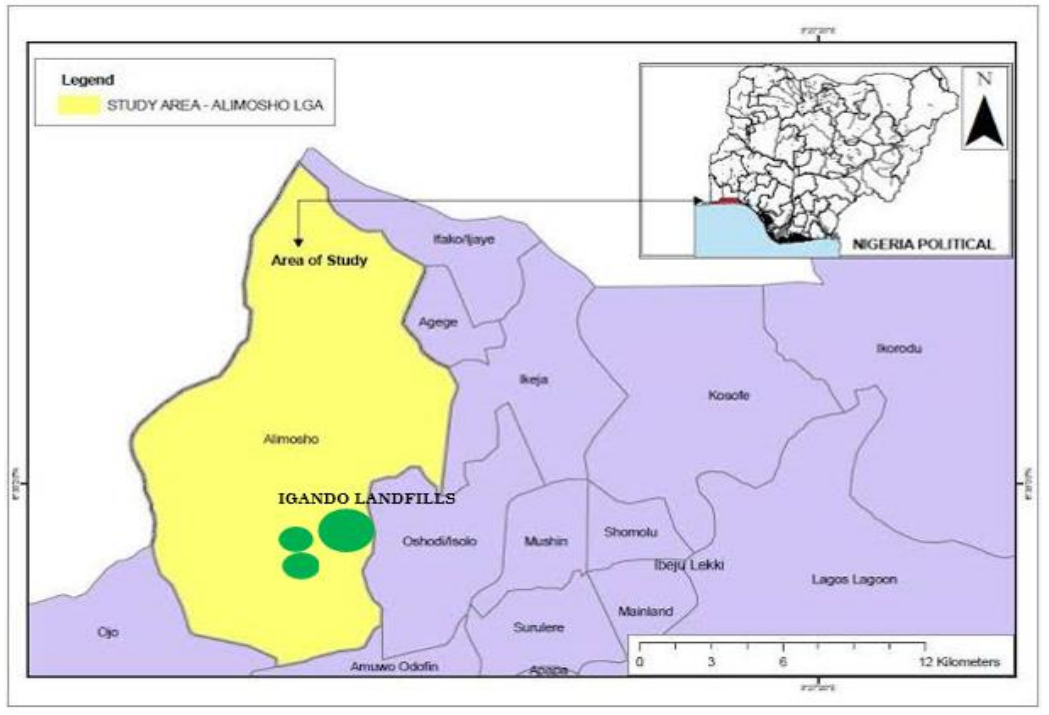

Fig. 1: The Study Area Igando Landfills in Alimoso Local Government Area

Igando is host community to both Alimoso Community Health centre and three solid waste management landfill facilities. The first of the three dumpsites was established in 1991 while the remaining two dumpsites were opened in 1994 and 2006 respectively. The three dumpsites namely Solous 1, Solous 2 and Solous 3 receive about 4000 tons of waste daily and occupy about 16.00 hectares of land. The dumpsites were not very far from the Alimoso Medical Centre and many other real estates. Initially, the facilities operated without much challenge to the population around but as time progressed and Igando became more populated, development spread to the facilities and the activities of the landfills consequently became a source of risk to the adjacent community populations.

Research design and methods of data collection: The study used two types of data sets namely the primary data and the secondary data. The primary data were drawn from the fieldwork survey of residents conducted between April and May 2019 using a structured questionnaire with the sole purpose of extracting information on their socio-demographic attributes and the effects of the solid waste landfill on the social, economic and health wellbeing of the residents in the area. The secondary data consisted in the maps and population data drawn from the Local Government Area archives. The target population for the study consisted of all the households in Igando area where the landfill facilities were located. The population of the study covered five (5) political wards of the Alimoso Local Government Area of Lagos State. The residents in this area in connection with their geographical environment were the focus of the study. Using empirical method one hundred and twenty (120) respondents served as the sample size for the study. The sampling frame was based on the number of building in the area and the location of the dumping sites. Systematic random sampling method was used to pick the respondents across wards in Igando area of Alimoso using structured questionnaire. Out of about 36 streets around the location 12 streets were randomly chosen for survey. A total of 10 respondents were interviewed per street. On each street survey began on the $2^{\text {nd }}$ house with an interval of 5 houses. One respondent per building was randomly chosen for interview. However, out of one hundred and twenty copies of administered questionnaire, one hundred copies of the questionnaire (100) were retrieved for analyses making $80 \%$ retrieval rate. The questionnaire was divided into three sections namely SECTION A which consisted of the demographic and socioeconomic background of the 
respondents, SECTION B which consisted of the impacts of dumpsites on socio-economic wellbeing and SECTION C which addressed the impacts of the dumpsites on the health and residential conditions of the people. The respondents were given the questionnaires to fill independently. The researcher assisted those who were not educated and unable to understand the content by reading and interpreting the questions to them.

Data Analysis: Data collected were analyzed using simple descriptive statistics and the inferential statistical method of chi-square. The null hypothesis Ho and the alternative hypothesis Ha were verified or tested using the chi-square $X^{2}=\sum(\boldsymbol{o}-\boldsymbol{e})^{2} / \boldsymbol{e}$ atalphalevelof $95 \%$. Where ' $\boldsymbol{o}$ ' represents observed frequency, ' $\boldsymbol{e}$ ' represents expected frequency. The degree of freedom DF for the test is (N-K), where ' $N$ ' represents the total sample or cases and ' $\boldsymbol{K}$ ' represents the number of variables. The null hypothesis (Ho) would be rejected if the calculated chi-square was higher than 0.05 or the tabulated value at $95 \%$ confidence level.

\section{RESULTS AND DISCUSSION}

Demographic and socio-economic characteristics of respondents: This section discusses the sociodemographic and economic attributes of the respondents that participated in the survey. Thereafter, data on the socio-environmental and health impacts of landfill sites in Igando were presented and discussed. The socio-demographic attributes discussed include gender, age, marital status, education, and income status. The impacts of landfill upon social, environmental and health status of the community residents were explained. In line with the objectives set in this study the socio-demographic characteristics of the respondents are to be analyzed and reported. TABLE 1 consists of information on the demographic distribution of the respondents that participated in the survey. The first aspects of the respondents examined in this study were the demographic compositions. According to information in TABLE 1the gender composition of the respondents is skewed towards the male who constituted 68 percents compared to the female group that constituted 32 percent. This indicates that male respondents are far more than females, because males are more approachable than females due to their level of understanding.

Table 1. Demographic attributes of respondents

\begin{tabular}{llll}
\hline Variable & Attribute Level & Number & Percentage \\
\hline
\end{tabular}

\begin{tabular}{llll}
\hline \multirow{3}{*}{ Gender } & Male & 68 & $68 \%$ \\
& Female & 32 & $32 \%$ \\
& Total & 100 & $100 \%$ \\
& Single & 36 & $36 \%$ \\
& Married & 48 & $48 \%$ \\
& Divorced & 12 & $12 \%$ \\
& Widowed & 4 & $4 \%$ \\
& Total & 100 & $100 \%$ \\
\hline
\end{tabular}

Source: Field Survey, 2019

Following gender distribution was the age composition of the respondents. FIG 2 shows that the middle age residents 31-40 years group was in the majority followed by the age group 20-30 years and the last group constituted the age group 41 years and above. This implies that the youth and the middle aged people formed the bulk of the respondents. It is obvious that, the highest percentage of respondents were younger age group while those at the age of 41 and above constituted just about $18 \%$.

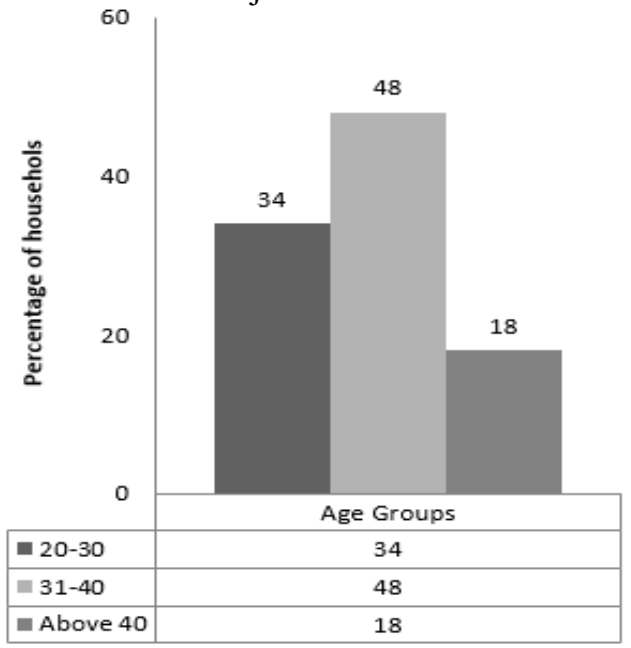

Fig. 2: Age distribution of respondents

One other attributes of the respondents interviewed in Igando was their marital status. According to TABLE 1 the marital status of the respondents were grouped into four namely single, married, divorced, widowed and the married with $48 \%$ of the respondents formed the majority, followed by the single $36 \%$ and the divorced who constituted $12 \%$. The least of the group was the widowed that constituted merely $4 \%$. The major problem here is the high dependency ratio, which affect the development of the society, because much pressure will be on some basic facilities e.g. electricity, water supply and housing. The effect of the demography variable on the environment in term of waste generation is that more than enough waste would be generated, because most of the respondents 
are from one household or the other and they generates different type of solid waste, which litters the surroundings and contaminated the ground water and also affects the health of the citizenry in general. TABLE 2 consists of information on the socioeconomic status of the respondents that participated in the survey. The first aspect of the socioeconomic attributes of respondents examined in this study was their educational attainment. TABLE 2 however shows that majority were educated to the secondary school level, while a sizeable $30 \%$ were educated to tertiary level and $4 \%$ were absolutely unlettered or uneducated. This information indicates that majority of the respondents interviewed were literate and could read and write. Also the job status of respondents was analyzed and results showed that majority of the respondents $68 \%$ were employed while $32 \%$ were either unemployed or retired. It is obvious that level of unemployed was high but this might have been influenced by the number of retired that joined the group.

Table 2.Socio-economic attributes of respondents

\begin{tabular}{llll}
\hline Variable & Attribute Level & Number & Percentage \\
\hline \multirow{5}{*}{ Educate } & $\begin{array}{l}\text { Educated To } \\
\text { Secondary }\end{array}$ & 66 & $66 \%$ \\
& $\begin{array}{l}\text { Level } \\
\text { Educated To } \\
\text { Tertiary Level }\end{array}$ & & \\
& No Formal & 04 & $40 \%$ \\
& $\begin{array}{l}\text { Education } \\
\text { Employed }\end{array}$ & 68 & $68 \%$ \\
Occupate & $\begin{array}{l}\text { Unemployed } \\
\text { /Retired } \\
\text { Total }\end{array}$ & 100 & $32 \%$ \\
\end{tabular}

As part of the socio-economic group were the income levels of the respondents. FIG 3indicates that out of the three groups, namely low income, middle income and high income earners, the middle income earners are in the majority while the high income earners were very few. This shows that these communities were peopled by the middle income residents who may be more vulnerable to the harmful effects of landfill pollution.

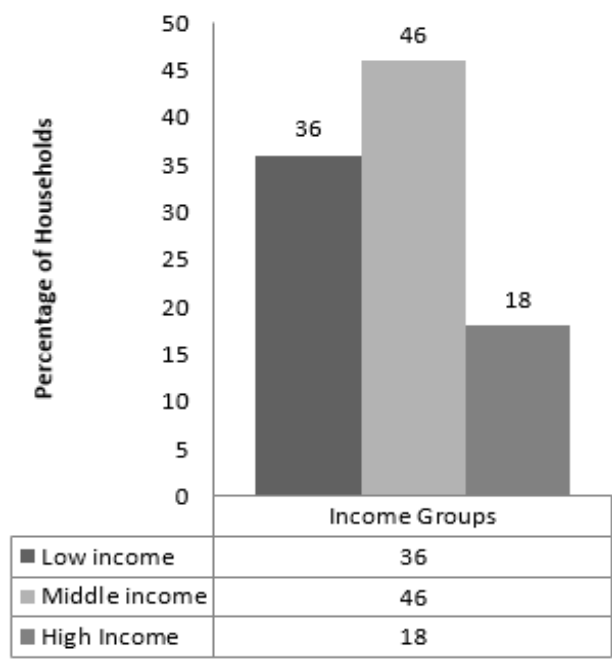

Fig. 3: Income status of respondents

Socio-environmental and Health effects of waste Landfills in Igando: The second and the third objectives set in this study were to analyze the socioenvironmental and health effects of waste landfills on the urban residents in Igando area of Lagos. TABLE 3 consists of results on the socio-environmental impacts of waste landfills is the study area. The impacts are in four categories namely flooding, fire, sewage/ground water pollution and traffic noise. Accordingly effects due to flooding accounted for the major environmental impacts of waste landfills in the area, followed by sewage pollution, and traffic problem. However, there was no report of fire incidences due to waste dumpsites. Results in TABLE 5 specifically show that effects on flooding accounted for $53 \%$, effects on groundwater pollution accounted for $27 \%$ while effects on traffic noise accounted for $20 \%$. Of course these findings support the study by Majolagbe et al (2017) which found that leachate from the dumpsite had polluting effects on the groundwater quality of the area.

Table 3. Socio-environmental effects of dumpsite

\begin{tabular}{llll}
\hline Variable & Attribute Level & Number & Percentage \\
\hline & Flood & 53 & $53 \%$ \\
Socio- & Fire & 00 & $00 \%$ \\
Environmental & Water Pollution & 27 & $27 \%$ \\
Effects & Traffic Noise & 20 & $20 \%$ \\
& Total & 100 & $100 \%$ \\
\hline & Source: Field survey, 2019 &
\end{tabular}

From the above table, it obvious that flooding is the most common environmental problem in the study area with 53 respondents are flooding followed by the sewage with 27 respondents and general health women with 20 respondents. The implication of this is that the 
solid waste been generated has blocked the entire drainage channel which lead to flooding. Apart from socio-environmental consequences dumpsites also posse health effects to the adjacent community residents. TABLE 4 shows that malaria fever is the most common sickness in the study area as a result of polluted environment of the respondents with 58 responses from different respondents followed by the Typhoid fever with 29respondents, cholera 10 respondents and Dysentery with 3 respondents which happened to be the least of all the sicknesses. These socio-environmental and health effects of dumpsites locations in the midst of residential neighborhoods confirmed studies from Nigeria and other parts of the world (Tomita, et al., 2020; Egbere et al., 2000; Majolagbe et al., 2019; Maloni et al., 2019). In fact these studies found empirical link between dumpsites and occurrence of typhoid, cholera and even child mortality.

\begin{tabular}{llll}
\multicolumn{4}{l}{ Table 4.Health effects of dumpsites in the study area } \\
\hline Variable & Attribute & Number & Percentage \\
& Level & & \\
\hline \multirow{4}{*}{ Potential } & Malaria & 58 & $58 \%$ \\
Diseases & Typhoid & 29 & $29 \%$ \\
& Cholera & 10 & $10 \%$ \\
& Dysentery & 03 & $3 \%$ \\
& Total & 100 & $100 \%$ \\
\hline \multicolumn{4}{c}{ Source: Field Survey, 2019 }
\end{tabular}

Impacts of waste dumpsites on residential conditions: TABLE5 shows the residential types and housing satisfaction in the study area affected by the environmental and health effects of dumpsites. Accordingly, the rooming housing predominates in Igando with about $56 \%$ of the dwellings being either one room or a room apartment type. Flat housing type constituted over one-quarter and duplex units constituted 10 percent. TABLE 6 shows the impacts of waste dump on residential values and satisfaction among the residents. The residents in the study area were less satisfied with their residency around the three dumpsites in Igando. In fact while about 67 percent of the respondents were unsatisfied due to the effects of the dumpsite in the area, 23 percent were fairly satisfied with their residential location relative to the dumpsites and 10 percent were very satisfied. The implications of these findings on the real estate valuation are very obvious as many potential home seekers would be avoiding the locations and this will eventually negatively affect the rental prices and lead to needless residential mobility (Ziraba et al., 2016; Majolagbe et al., 2109; Egbere et al., 2000).
Table 5. Residential types in Igando

\begin{tabular}{llll}
\hline Variable & $\begin{array}{l}\text { Attribute } \\
\text { Level }\end{array}$ & Number & Percent \\
\hline \multirow{3}{*}{ Housing } & Rooming & 56 & $56 \%$ \\
Types & Flat & 34 & $34 \%$ \\
& Duplex & 10 & $10 \%$ \\
& Total & 100 & $1000 \%$ \\
\hline \multicolumn{4}{c}{ Source: Field Survey, 2019 }
\end{tabular}

Table 6. Residential value and satisfaction effects of waste dumpsites in Igando

\begin{tabular}{|c|c|c|c|}
\hline Variable & $\begin{array}{l}\text { Attribute } \\
\text { Level }\end{array}$ & Number & Percent \\
\hline \multirow{3}{*}{$\begin{array}{l}\text { Residential } \\
\text { Value }\end{array}$} & High & 60 & $60 \%$ \\
\hline & Effects & & \\
\hline & $\begin{array}{l}\text { Little } \\
\text { Effects }\end{array}$ & 32 & $32 \%$ \\
\hline \multirow{8}{*}{$\begin{array}{l}\text { Residential } \\
\text { Satisfaction }\end{array}$} & $\begin{array}{l}\text { No } \\
\text { Effects }\end{array}$ & 08 & $8 \%$ \\
\hline & Total & 100 & $100 \%$ \\
\hline & Highly & 10 & $10 \%$ \\
\hline & Satisfied & & \\
\hline & Fairly & 23 & $23 \%$ \\
\hline & Not & 67 & $67 \%$ \\
\hline & Satisfied & & \\
\hline & Total & 100 & $100 \%$ \\
\hline
\end{tabular}

Hypothesis Testing: A hypothesis was tested for veracity in the study and it was on whether the level of diseases reported is related with the dumpsites in the area. Specifically the hypothesis was expressed thus:

Ho: That the location of the dumping site does not contribute to the type of sickness affecting the respondents.

Ha: That the location of the dumping site contribution to the type of sickness affecting the respondents.

Table 7. Chi-square analysis of effects of dumpsites on disease

\begin{tabular}{llllll}
\hline \multicolumn{6}{c}{ occurrence in Igando } \\
\hline Disease & $\mathrm{O}$ & $\mathrm{e}$ & $\mathrm{O}-\mathrm{e}$ & $(\mathrm{O}-\mathrm{e})^{2}$ & $\sum(\mathrm{O}-\mathrm{e})^{2} / \mathrm{e}$ \\
\hline Malaria & 58 & 25 & 33 & 1084 & 43.56 \\
Typhoid & 29 & 25 & 4 & 16 & 0.64 \\
Cholera & 10 & 25 & -15 & 225 & 9.00 \\
Dysentery & 3 & 25 & -22 & 484 & 19.36 \\
Total & 100 & 100 & 0 & 1814 & 72.56 \\
\hline \multicolumn{5}{c}{ Source: Field Survey, 2019}
\end{tabular}

The hypothesis shows whether or not, the location of the dumping site contributed to the type of sickness of the respondents. As shown in TABLE 7 the hypothesis was verified using the chi-square at 0.05 significance levels. The expected value was estimated to be 25 while the DF was 4 . Hence, $\boldsymbol{X}^{2}=\sum(\boldsymbol{O}-\boldsymbol{e})^{2} / \boldsymbol{e}=72.56$. At 4 degree of freedom (DF) and 0.05 level of 
significance, Chi-square $\boldsymbol{X}^{2}$ table value $=9.49$ and Chisquare $X^{2}$ calculated value $=72.56$. Therefore based on the analysis from TABLE7, the hypothesis the null hypothesis (Ho) that location of the dumping site does not contribute to the type of sickness affecting the respondents was rejected. The alternative hypothesis (Ha) that says the location of dumpsites contributes to the type of sickness affecting the respondents was held to be true. This implies that residents of the study area suffered from various ailments ranging from malaria, typhoid fever, cholera, to dysentery due to the dumpsites around the community. This confirms studies that have found that waste dumpsites could be associated with the incidences of epidemics such as dysentery, cholera and cancer (Tomita et al., 2020; Ziraba et al., 2016; Przydatek and Kanownik, 2019; Mataloni et al., 2016).

Conclusions: This study has analyzed and appraised the public perception of solid waste management, the effects of dumpsites on the housing, economic, social, environmental and health conditions of Igando community in Alimoso local government area of Lagos. The major findings of the study pointed at waste dumpsites as constituting negative social, residential, environmental and health externalities to the residents. These findings are consistent with previous studies from many parts of the world. This study suggests a relocation of the dumpsites away from the midst of urban population and establishment of modern waste treatment facilities as permanent solutions to the solid waste management problems in Lagos.

\section{REFERENCES}

Agunwamba, JC (1998). Solid waste management in Nigeria: Problems and Issues. J. Environ. Manage. 22(6): 849-856

Agunwamba, JC (2003). Analysis of scavengers' activities and recycling in some cities of Nigeria. Environ. Manage. 32(1): 116-127

Agwu, MO (2012). Issues and Challenges of solid waste management practice in Port Harcourt City, Nigeria- A behavioral perspective. Am. J. Soc. Manage. Sci. 3(2): 83-92

Aliu, IR; Adeyemi, EO; Adebayo, A (2014). Municipal household solid waste collection strategies in an African megacity: Analysis of private public partnership (PPP) performance in Lagos. Waste Manage. Res. 32(9-suppl): 67-78

Babalola, JO (2008). A study of hospital waste generation and management practice in Akure, Nigeria. African Research Review 2(3): 292-305

Egbere, OJ; Itelima, JU; Opiah, FO (2000). Municipal solid waste segregation and their health hazard implications in Agwan-Rogo ward of Jos, Plateau State, Nigeria. Journal of Environmental Science 4(1): $1-4$

Kaza, S; Yao, L; Bhada-Tata, P; Van Woerden, F (2018). What a waste 2.0: A global snapshot of solid waste management to 2050. Washington DC: World Bank

Lasisi, KS (2007). An appraisal of municipal solid waste management in Lagos State. Ibadan: Longman publication

Majolagbe, AO; Adeyi, AA; Osibanjo, O; Adams, A O; Ojuri, OO (2017). Pollution vulnerability and health risk assessment of groundwater around an engineering landfill in Lagos, Nigeria. Chemistry International 3(1): 58-68

Mataloni, F; Badaloni, C; Golini, MN (2016). Morbidity and mortality of people who live close to municipal waste landfills: A multisite cohort study. International Journal of Epidemiology 45: 806-815

Momoh, JJ; Oladebeye, DH (2010). Assessment of awareness, attitude and willingness of people to participate in household solid waste recycling programme in Ado-Ekiti, Nigeria. J. Appl. Sci. in Environ. Sanitat. 5(1): 93-105

Odumosu, T (2000). When refuse dumps become "mountains": Responses to waste management in metropolitan Lagos. In Tesi, M.K. (Ed.).The Environment and Development in Africa. Maryland USA: Lexington Publishers

Ogwueleka, TC (2003). Analysis of urban solid waste in Nsukka Nigeria. J. Solid Waste Techn. Manage. 29(4): 239-246

Ogwueleka, TC (2009). Municipal solid waste characteristics and management in Nigeria. Iran J. Environ. Health Sci. Eng. 6(3):173-180 
Olorunfemi, FB (2011). Landfill development and current practices in Lagos metropolis, Nigeria. $J$. Geography and Regional Planning 4(12):656-663

Przydateck, G; Kanownik, W (2019). Impact of small municipal solid waste landfill on groundwater quality. Environ. Monit. Assess. 191: 169

Salami, L; Susu, AA (2019). A comprehensive study of leachate characteristics from three Solous dumpsites in Igando area of Lgos, State Nigeria. Global J. Environ. Manage. Pub. Safety 8(1): 1-14

Shamshiry, E; Nadi, B; Bin-Mokhtar, M; Komoo, I; Hashim, HS; Yahaya, N (2011). Integrated models for solid waste management in tourism region: Langkawi Island, Malaysia. J. Environ. Public Health: DOI: http://doi.org/10.1155/2011/709549

Tomita, A; Cuadros, DF; Burns, JK; Tanser, F; Slotow, R (2020). Exposure to waste sites and their impact on health: A panel and geo-spatial analysis of nationally representative data from South Africa, 2008-2015. Lancet Planet Health, 4, e223234
Ukpong, IE; Udofia, EP (2011). Domestic solid waste management in a rapidly growing Nigerian City of Uyo. J. Human Ecol. 36(3): 229-235

UNHABITAT (2010). Collection of municipal solid waste in deveoping countries. Nairobi: United Nations Human Settlement Programme. http://www.unhabitat.org

Ziraba, AK; Haregu, TN; Mberu, B (2016). A review and framewok for understanding the potential impact of solid waste management on health in developing countries. Arch Public Health, 74: 55

Wilson, CD; Schinberg, A (2010). What is good practice in solid waste mnagement? Waste Management and Research 28(12): 1055-1056. 